\title{
Timing of Langhian bioevents in the Carpathian Foredeep and northern Pannonian Basin in relation to oceanographic, tectonic and climatic processes
}

\author{
Katarína HOLCOVÁ ${ }^{1, *}$, Nela DOLÁKOVÁ ${ }^{2}$, Slavomír NEHYBA ${ }^{2}$ and František VACEK ${ }^{3}$ \\ 1 Charles University, Institute of Geology and Palaeontology, Albertov 6, 12843 Praha 2, Czech Republic \\ 2 Masaryk University, Institute of Geological Sciences, Faculty of Science, Kotlářská 2, 61137 Brno, Czech Republic \\ 3 National Museum, Václavské náměstí 68, 11579 Praha, Czech Republic
}

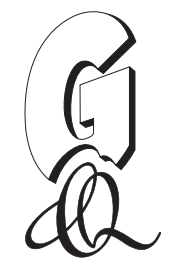

\begin{abstract}
Holcová, K., Doláková, N., Nehyba, S., Vacek, F., 2018. Timing of Langhian bioevents in the Carpathian Foredeep and northern Pannonian Basin in relation to oceanographic, tectonic and climatic processes. Geological Quarterly, 62 (1): 3-17, doi: 10.7306/gq.1399

The succession of bioevents in planktonic foraminifer and calcareous nannoplankton communities is reviewed and summarized for the Carpathian Foredeep and northern Pannonian Basin in the time interval between $\sim 16$ and $13.5 \mathrm{Ma}$. This succession can be subdivided into three principal intervals: (1) an interval with rare Praeorbulina sicana and P. glomerosa. It was characterized by a limited immigration of index taxa linked to the lack of a warm surface water layer in the Central Paratethys. This interval can be correlated with the first Badenian transgression near the Burdigalian/Langhian boundary. The rare occurrence of biostratigraphical markers does not allow its precise dating and interregional correlation; (2) a brief interval of the first occurrences of Praeorbulina circularis, Orbulina suturalis and Helicosphaera waltrans. This can be related to the formation of a warm surface water layer suitable for the survival of orbulinas and praeorbulinas and a change from estuarine to anti-estuarine circulation. This interval can be correlated with the second Badenian transgression, which, however, was not isochronous over the area as inferred from different successions of these first occurrences; (3) a limited appearance of new index taxa in the Central Paratethys prior to the Wielician Salinity Crisis. This time interval was characterized by increased seasonality and salinity oscillations followed by climate cooling. A "reverse" migration of the stress-tolerant species Helicosphaera walbersdorfensis from the Central Paratethys to the Mediterranean is suggested. Several local bioevents with limited stratigraphic correlation potential have been recognized in this interval.
\end{abstract}

Key words: Miocene, Central Paratethys, biostratigraphy, calcareous nannoplankton, foraminifera, palynology.

INTRODUCTION

The correlation of the Langhian Stage with the local Central Paratethys stratigraphy has been recently widely discussed. Piller et al. (2007) correlated its base with the Karpatian/Badenian boundary. This boundary, defined by the first occurrence of Praeorbulina (Papp et al., 1978), was subsequently redefined by Hohenegger et al. (2014) to a level corresponding to the uppermost Burdigalian. This correlation was based on dating of the first occurrence of Praeorbulina in the world oceans. The top of the Langhian is correlated with the Moravian/Wielician local substage boundary (i.e., Early/Middle Badenian sensu Papp et al., 1978). Hohenegger et al. (2014) proposed correlation of the Moravian substage with the Early and Middle Badenian. However, this new subdivision is not generally accepted and causes confusion in terminology and stratigraphic correlations.

\section{* Corresponding author, e-mail: holcova@natur.cuni.cz}

Received: September 12, 2017; accepted: November 29, 2017; first published online: January 26, 2018
The Badenian marine biostratigraphy based on local (eco)zones of Grill (1943) and Cicha et al. (1975) has been generally accepted since the 1970s (Papp et al., 1978). However, complementary stratigraphic data such as magnetostratigraphy (Hohenegger et al., 2009a; Selmeczi et al., 2012; de Leeuw et al., 2013) and new radiometric and Sr-ages (Radócz, 2004; Handler et al., 2006; de Leeuw et al., 2010; Fordinál et al., 2014) showed that the concept of such a seemingly distinct system no longer applies even for the local stratigraphy (Hohenegger et al., 2014).

Despite emerging new stratigraphical methods and data, biostratigraphy remains the most widely used correlation method. The occurrence of common index taxa that migrated in the system of interconnected basins enable interregional correlations of the Lower Badenian deposits in the Central Paratethys (Rögl, 1998; Popov et al., 2004). However, the timing of such bioevents was not entirely synchronous in the individual basins with many factors, such as local tectonics and climate, water chemistry and circulation regime, playing a role in their distribution.

In this paper we discuss the timing of the Langhian Central Paratethys bioevents based on a case study of the northern Pannonian Basin and the Moravian part of the Carpathian Foredeep. Our results are compared to the world oceans 
and/or the Mediterranean region and the recorded differences are related to climatic, oceanographic and tectonic factors that may have affected the spatial and temporal distribution of index microorganisms.

\section{GEOLOGICAL SETTING}

Our study area includes the Pannonian Basin System (South Slovak Basin) and the Carpathian Foredeep (Seneš, 1961; Fig. 1).

The South Slovak Basin (SSB) belongs to the northeastern part of the Pannonian Basin System. The area was inundated from the Oligocene to the Ottnangian (Middle Burdigalian) and then again during the Karpatian (Late Burdigalian). After the late Early Miocene upheaval event, the subsidence was rejuvenated around the Karpatian/Badenian (Burdigalian/Langhian) boundary but only for a short time. Sedimentation was controlled by NNW-SSE faults and was accompanied by the Badenian marine transgression. Depocentres were situated in the west where the SSB continued to the Danube Basin. Subsidence was followed by a volcanic paroxysm and extensive volcanism in adjacent terrestrial and marine areas. Volcanic bulging caused rapid uplift and marine regression in the area (Vass, 1995; Vass et al., 2007).

Sedimentation in South Slovakia started with the tide-influenced Pribelce Member overlain by the Vinica Formation deposited in littoral to neritic environments. Tuffaceous sandstones and siltstones with common bioturbation dominated by domichnia overlie the basal coarse volcaniclastic deposits. Algal bioherms locally occur within the sandstones and siltstones (Vass et al., 2007).

The formation and basin evolution of the Carpathian Foredeep (CF) - as a peripheral foreland basin - was related to the subsurface loading of the Alpine-Carpathian orogenic belt on the Bohemian Massif margin during the Early to Middle Miocene (Nehyba and Šikula, 2007; Nehyba et al., 2008). The basin continues south into the Alpine Molasse Zone and north into the Polish segment of the CF Basin (Oszczypko et al., 2006). The infill and basin architecture varies throughout the CF Basin, local and regional unconformities are developed due to the varying intensity and orientation of flexural loading and different geological and tectonic histories of the basement, along with a polyphase nature of the active basin margin and gradual change of its position (Brzobohatý and Cicha, 1993; Nehyba, 2000; Kováč et al., 2004; Oszczypko et al., 2006).

The stratigraphic range of the sedimentary infill of the studied CF Basin segment is Eggerian to Lower Badenian (Brzobohatý and Cicha, 1993). The Lower Badenian deposits reveal a distinctive basin infill geometry because they are almost symmetrically located in the central parts of the basin. The Lower Badenian sedimentary sequence is dominated by a lithologically uniform package of pelitic sedimentary strata (known as "Tegel") with a thickness reaching several hundreds of metres. These pelites are interpreted as deposits of the middle to outer shelf or even hemipelagites (Papp et al., 1978; Cicha, 2001; Nehyba et al., 2008). Coarse-grained sandstones and conglomerates represent the second dominant lithofacies being generally described as "basal or marginal coarse clastics" (Krystek, 1974; Nehyba et al., 2008). Bioherms of red-algal limestones (Doláková et al., 2008) form laterally and volumetrically restricted bodies within the mudstones. Thin volcanoclastic beds (acidic tuffs and tuffites) interpreted as distal tephra fallout are rare (Nehyba et al., 1999).

\section{MATERIALS AND METHODS}

We synthesize multiproxy data from boreholes from the CF: LOM-1 (Holcová et al., 2015a), ZIDL-1 and ZIDL-2 (Doláková et al., 2014), RY-1 (Kopecká, 2012), OV-1 and OV-2 (Nehyba et al., 2016); from the SSB (boreholes $\mathrm{N}-45, \mathrm{~N}-48, \mathrm{~N}-68, \mathrm{~N}-80$, N-83, N-95, N-91; Holcová et al., 1996; for location of all boreholes see Fig. 1). In addition, palynological data from the following boreholes from the CF were used: IK-1 (Basistová and Doláková, 2011; Doláková et al., 2011), HJ-1, HJ-2, HJ-103 (Hladilová et al., 1999, 2001).

Foraminifera were analysed in the fraction between 0.063 and $2 \mathrm{~mm}$, calcareous nannoplankton was studied from smear slides. Assemblage quantitative evaluation was based on 200-300 specimens for foraminifera and 300-500 specimens for calcareous nannoplankton. The method of Zágoršek et al. (2007) was used for our purposes.

Standard maceration in $\mathrm{HCl}(20 \%), \mathrm{HF}, \mathrm{KOH}$ and $\mathrm{HCl}$ $(10 \%)$ and $\mathrm{ZnCl}_{2}$ (density $=2 \mathrm{~g} / \mathrm{cm}^{3}$ ) was used for palynological samples. Pollen diagrams were processed using POLPAL software (Walanus and Nalepka, 1999) with a minimum of 150 determined pollen grains and spores, excluding Pinus and undetermined conifers. The terminology of Stuchlik et al. (1994), Kvaček et al. (2006) and Kovar-Eder et al. (2008) was employed for the classification of vegetation units.

We have used published $\delta^{18} \mathrm{O}$ data from foraminiferal tests for further palaeoenvironmental interpretations (Holcová and Demeny, 2012; Doláková et al., 2014; Scheiner, 2015). Four different datasets have been distinguished, each characterizing specific levels in the water column: (1) data from Globigerinoides bulloides characterize surface waters during periods of enhanced productivity (probably spring bloom; Schiebel et al., 1997); (2) data from Globigerinoides characterize surface summer stratified waters (Reynolds and Thunell, 1985; Hemleben et al., 1989), (3) data from epifaunal Cibicidoides spp. reflect the quality of the bottom water (Kaiho, 1994; Murray, 2006); (4) pore water chemistry in the sediment was documented by isotopic values from shallow infaunal Melonis spp. and Gyroidina spp. and deep infaunal Uvigerina spp. (Caralp, 1989; Hermelin, 1992; Sjoerdsma and Van der Zwaan, 1992; Sen Gupta and Machain-Castillo, 1993; Miao and Thunell, 1993; Rathburn and Corliss, 1994).

\section{PALYNOLOGICAL ANALYSIS}

Two principal zonal forest assemblages have been recognized from the study of palynoflora: (1) subtropical broad-leaved forests characterized by a high abundance of evergreen elements (relative abundance up to $38 \%$ ), such as Sapotaceae, palms, Engelhardia, Platycarya, evergreen Fagaceae, Reevesia, Cornus-Mastixia, and Rutaceae; (2) a warm to temperate mixed mesophytic and broad-leaved deciduous forest type with broad-leaved elements (relative abundance 12-21\%), i.e., Quercus, Celtis, Juglans, Tilia, Betula, and Acer. Increased diversity and quantity of "deciduous oak type" pollen grains have been recorded here by contrast with the Lower Miocene. Occurrences of mountain forest components (Cedrus, Tsuga and Picea; Doláková et al., 1999, 2011, 2014; Kováčová et al., 2011), coastal swamp (Taxodiaceae, Cyrillaceae, Myricaceae, Decodon) and riparian elements (Alnus, Salix, Ulmus, Fraxinus, Liquidambar, Carya) indicate the complex nature of zonal biotopes in the adjacent areas.

The highest proportion of thermophilous floral elements/lowest percentage of arctotertiary elements were de- 

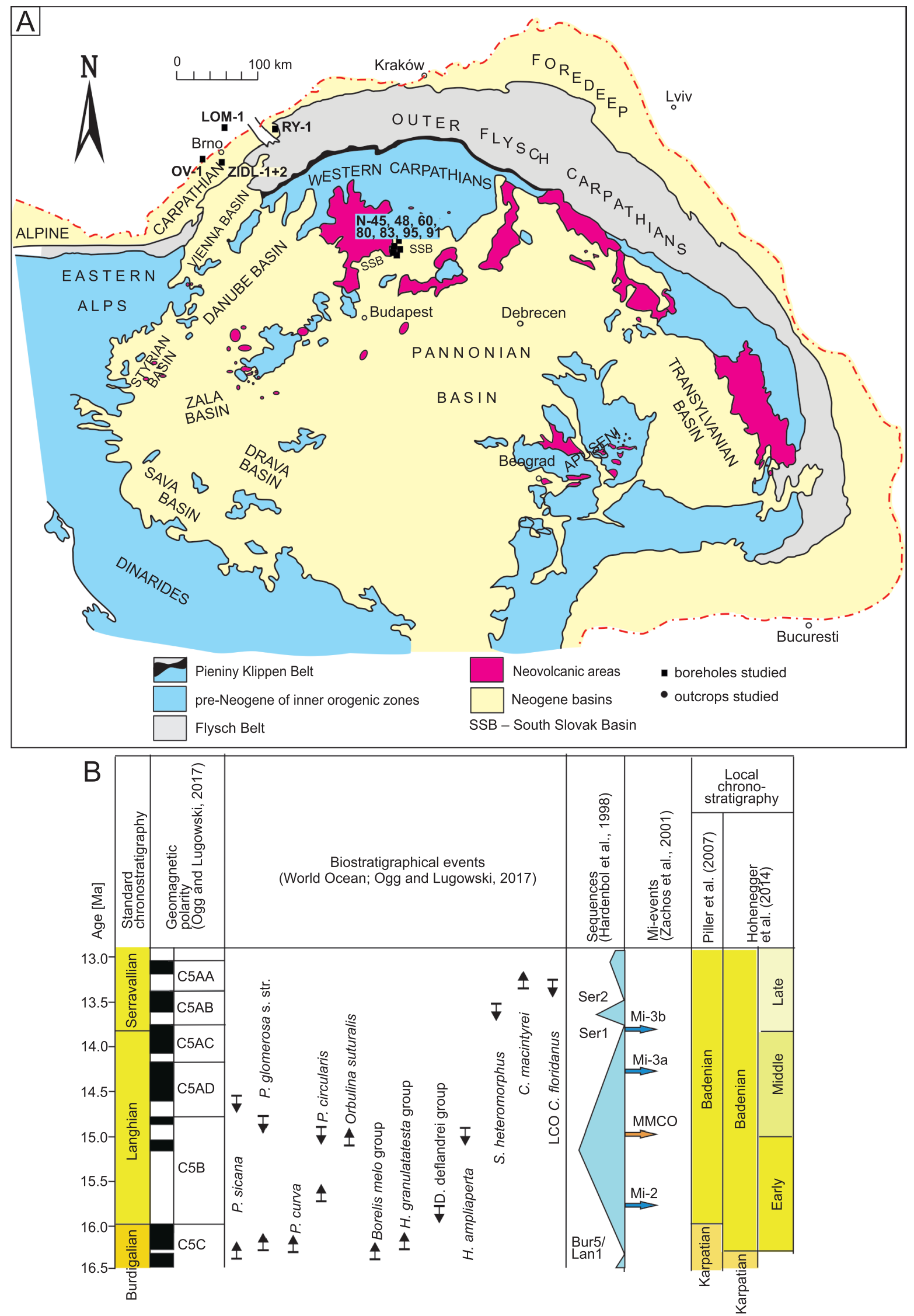

Fig. 1A - schematic map of the areas under study and their positions within the Carpatho-Pannonian region with location of the sections studied (map modified from Kováč et al., 2007); B - chrono-, bio- and magnetostratigraphy of the interval studied 
tected in palynospectra from the interval with Praeorbulina sicana and $P$. glomerosa. A relatively lower abundance of xerophilous elements such as Engelhardia and Olea has been observed here (Fig. 2A).

An increase in abundance of arctotertiary elements that coincides with increased abundances of xerophilous markers (such as dry herbs and heliophytes Olea, Poaceae, Asteraceae, Caryophyllaceae, Chenopodiaceae, Ericaceae) can be seen in the short interval between the FOs of Praeorbulina circularis and Orbulina (Fig. 2B, C). The disappearance of Sapotaceae and decrease in Cornoideae-Mastixioideae and evergreen Fagaceae and increase in arctotertiary elements were recorded around the LCO of Helicosphaera waltrans.

The interval with Orbulina suturalis and common $H$. walbersdorfensis is characterized by a dominance of conifers and marine dinoflagellates (sometimes referred to as the Pinus event; Fig. 2D). Pollen and spores completely disappear higher in the section in many of the boreholes studied.

\section{BIOEVENTS SUCCESSION AND RELIABILITY OF THEIR USE IN STRATIGRAPHY}

Several prominent bioevents have been recognized in the boreholes and sections studied. Their potential for local and interregional biostratigraphy is discussed below.

The first occurrences of Praeorbulina sicana and $P$. glomerosa and the last occurrence of Helicosphaera ampliaperta. The interval below the first occurrences (=FOs) of Helicosphaera waltrans, Praeorbulina circularis and Orbulina suturalis is characterized by scattered occurrences of Praeorbulina sicana and P. glomerosa (Appendix $1 A^{*}$ ) that cannot be used for any reliable stratigraphic correlations. Helicosphaera ampliaperta rarely occurred in this interval; however, the position of its last occurrence $(=\mathrm{LO})$ is inaccurate due to its scarcity along the sections (Appendix 1D). Its possible redeposition must also be taken into consideration.

The first occurrences of Praeorbulina circularis and Orbulina suturalis. The FOs of Praeorbulina circularis and Orbulina suturalis represent a very distinct bioevent. Besides the appearance of new index taxa, the abundance of plankton from the Orbulina-Praeorbulina group is considerably higher by contrast with the previous interval (Appendix 1A).

The FO of Praeorbulina circularis slightly preceded the FO of Orbulina suturalis. Before this event, the Coccolithus pelagicus/Reticulofenestra minuta ratio changed (Appendix 1B).

The last common occurrence of Helicosphaera waltrans and the last occurrence of Sphenolithus heteromorphus. Quantitative analyses of calcareous nannoplankton assemblages showed increased relative abundance of $H$. walbersdorfensis (Appendix 1C). The last common occurrence $(=\mathrm{LCO})$ of $H$. waltrans coincides with increased abundances of $H$. walbersdorfensis and can be used as a reliable stratigraphical marker (Appendix 1C). This event occurred after the FO of Orbulina. Above the LCO, $H$. waltrans has been recorded only discontinuously in several samples.

The LO of S. heteromorphus is not a reliable marker in the sections studied because of its scarce occurrences (Appendix 1D). Marunteanu (1999) and Bartol (2009) recommended using the decreased abundance of Cyclicargolithus floridanus as an auxiliary indicator in the Central Paratethys. However, this has not been recognized in our study material (Appendix 1E) nor have other synchronous bioevents described (the LOs of discoasters, the FCO of Reticulofenestra pseudoumbilica $>7 \mu \mathrm{m}$; Bartol, 2009).

Local bioevents: acme of Reticulofenestra minuta, Spiroplectinella carinata and Globorotalia transylvanica. The high abundance of Reticulofenestra minuta is characteristic of the studied sections above the FO of Helicosphaera waltrans (Appendix 1B). An increase in R. minuta abundance coincides with increasing numbers of $H$. walbersdorfensis ( $r=$ $0.74 ; p<0.001$ ) and decrease in C. pelagicus. A negative correlation of relative abundances of $H$. walbersdorfensis and $C$. pelagicus species can also be detected $(r=-0.56 ; p<0.001)$. The levels above the LCO of $H$. waltrans are characterized by higher variations in $R$. minuta frequency compared to the underlying interval (Appendix 1B).

An increase in abundance of biserial agglutinated foraminifera (primarily Spiroplectinella carinata) may be used for definition of a local (eco)zone Spiroplectinella carinata (Grill, 1943) that corresponds to the Middle Badenian sensu Papp et al. (1978). The stratigraphic distribution of this morphogroup, summarized in Appendix 1F, showed that the increase in abundance occurred above the LCO of Helicosphaera waltrans. However, this event has been recognized only locally (LOM-1, RY-1 and ZIDL-2 boreholes).

A G. transylvanica acme was recorded in the Polish and Romanian part of the CF prior to the Wieliczka salinity crisis. The generally positive trend in relative abundance of these endemic taxa with several cyclic oscillations detected in our samples (Appendix 1G) may indicate that a single G. transylvanica acme may be only a locally restricted event.

\section{INTERREGIONAL CORRELATIONS AND BIOEVENTS TIMING}

The first occurrences of Praeorbulina sicana and $P$. glomerosa. In accordance with our observations, Praeorbulina sicana and $P$. glomerosa have been recorded only discontinuously throughout the Central Paratethys in the time interval before the FO of Orbulina. Both species have been rarely found in the Styrian Basin (Spezzaferri et al., 2009; Hohenegger et al., 2009a), the Alpine Foredeep Basin (Austrian Mollase Basin; Ćorić et al., 2004), the Danube Basin (Rybár et al., 2015, 2016), the South Slovak Basin (Vass et al., 2007) and the Polish part of the CF (Oszczypko and Oszczypko-Clowes, 2012). This interval corresponds to local biozone of Globigerinoides sicanus (Cicha et al., 1975).

Bioevent numerical dating in this lineage for the Central Paratethys is not generally accepted due to the absence of reliable radiometric dating control. The timing of the praeorbulinas' first occurrences in the Mediterranean region markedly differs from those in the world oceans (Abdul Azis et al., 2008; Turco et al., 2011; Wade et al., 2011; Gradstein et al., 2012; Fig. 3). The use of bioevents for correlation between the global magnetostratigraphical chart and detected chrons in our study area may be misleading. A presumed pathway between the Atlantic/Indo-Pacific and the Central Paratethys in this period passed through the Mediterranean (Rögl, 1999; Popov et al., 2004; Kováč et al., 2007, 2017a, b) to present-day Slovenia and Croatia (this interval was reported from this region by Cicha et al., 1975; Bartol, 2009). A strongly hypothesized direct connection between the Paratethys and the Indo-Pacific realm may 
A Thermophylous markers

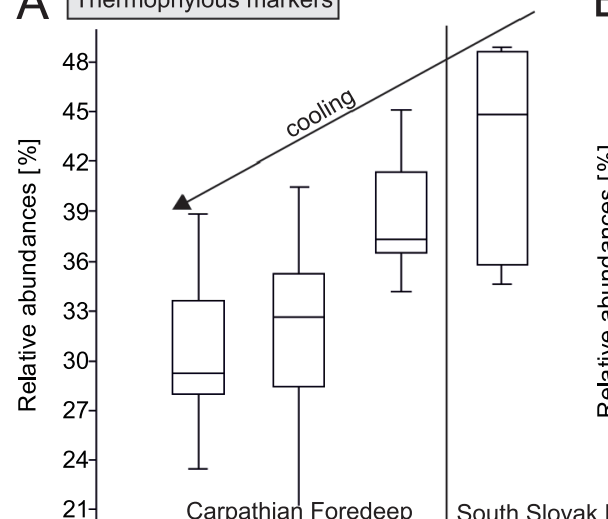

B Arctotertiary markers

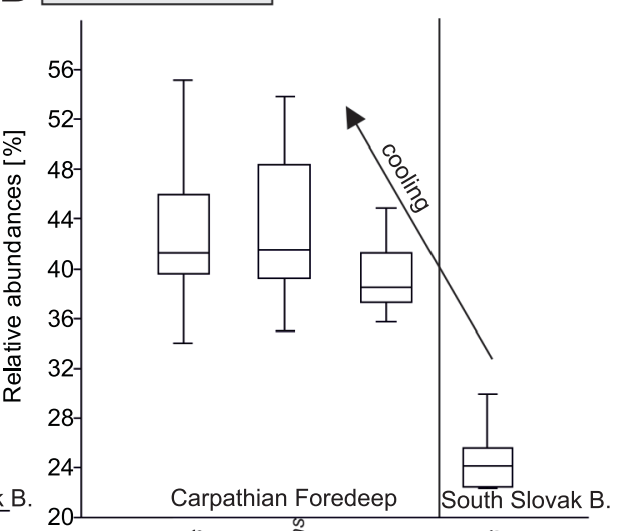
thian Foredeep

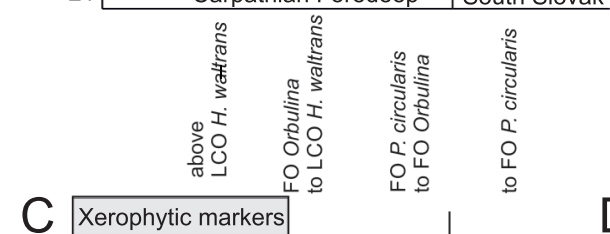

C Xerophytic markers

$\frac{5}{0}$
$\frac{0}{3}$
0
$\frac{0}{0}$
0
0
0
4
0

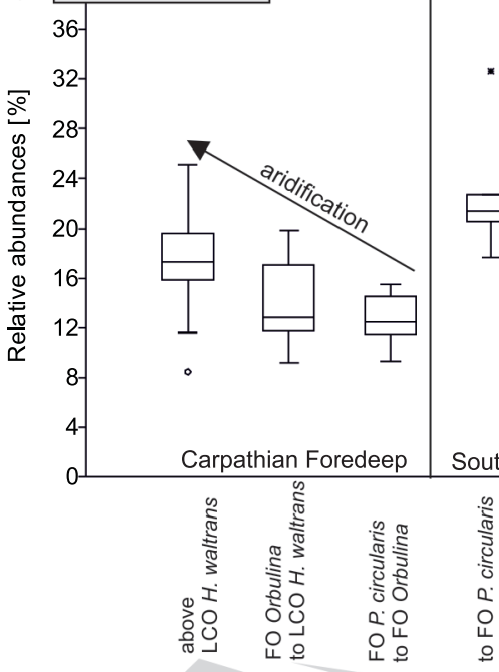

Pinus + Cathaya types
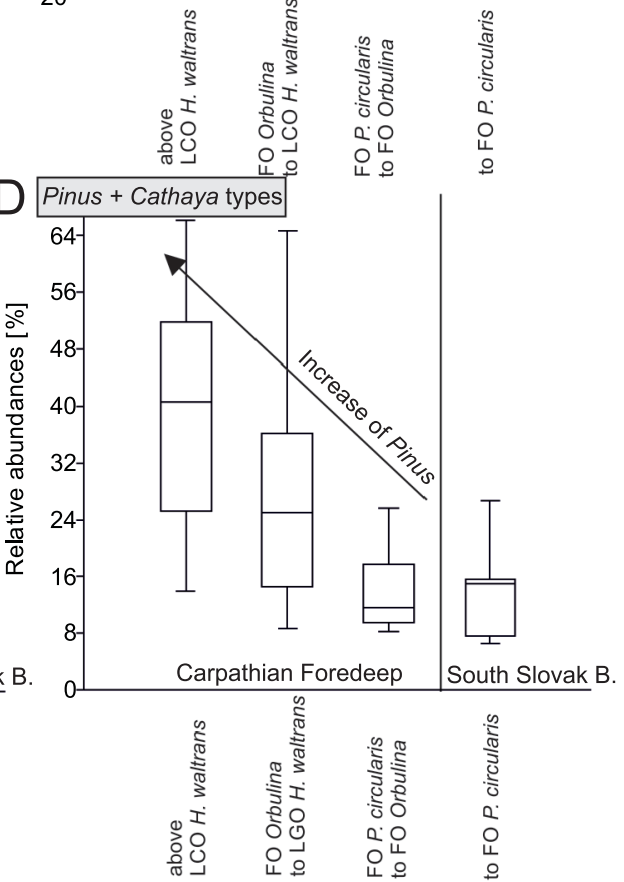

$\delta \mathrm{O}^{18}$ values in foraminiferal tests
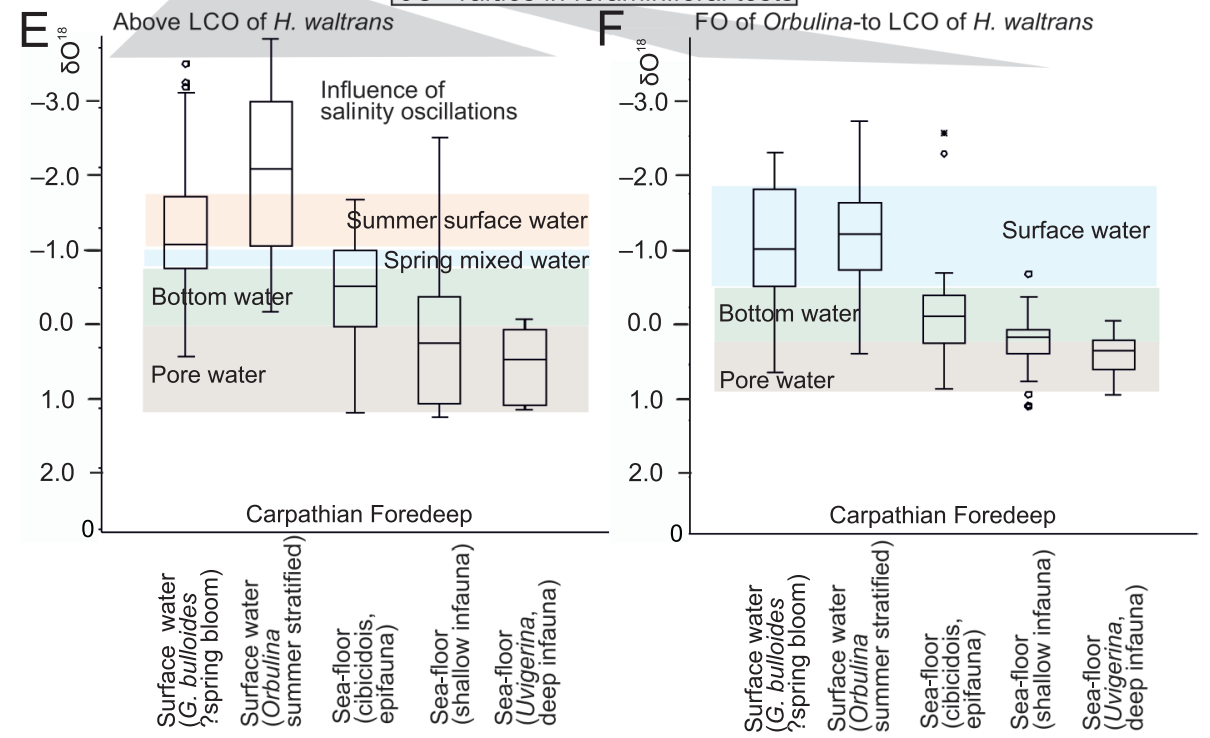

Fig. 2. Relative abundances of palaeoclimatological markers (A-D) terrestrial palynomorphs (E, F) $\delta{ }^{18} \mathrm{O}$ values (data from Holcová and Demeny, 2012; Doláková et al., 2014; Holcová et al., 2015b; Scheiner, 2015) 


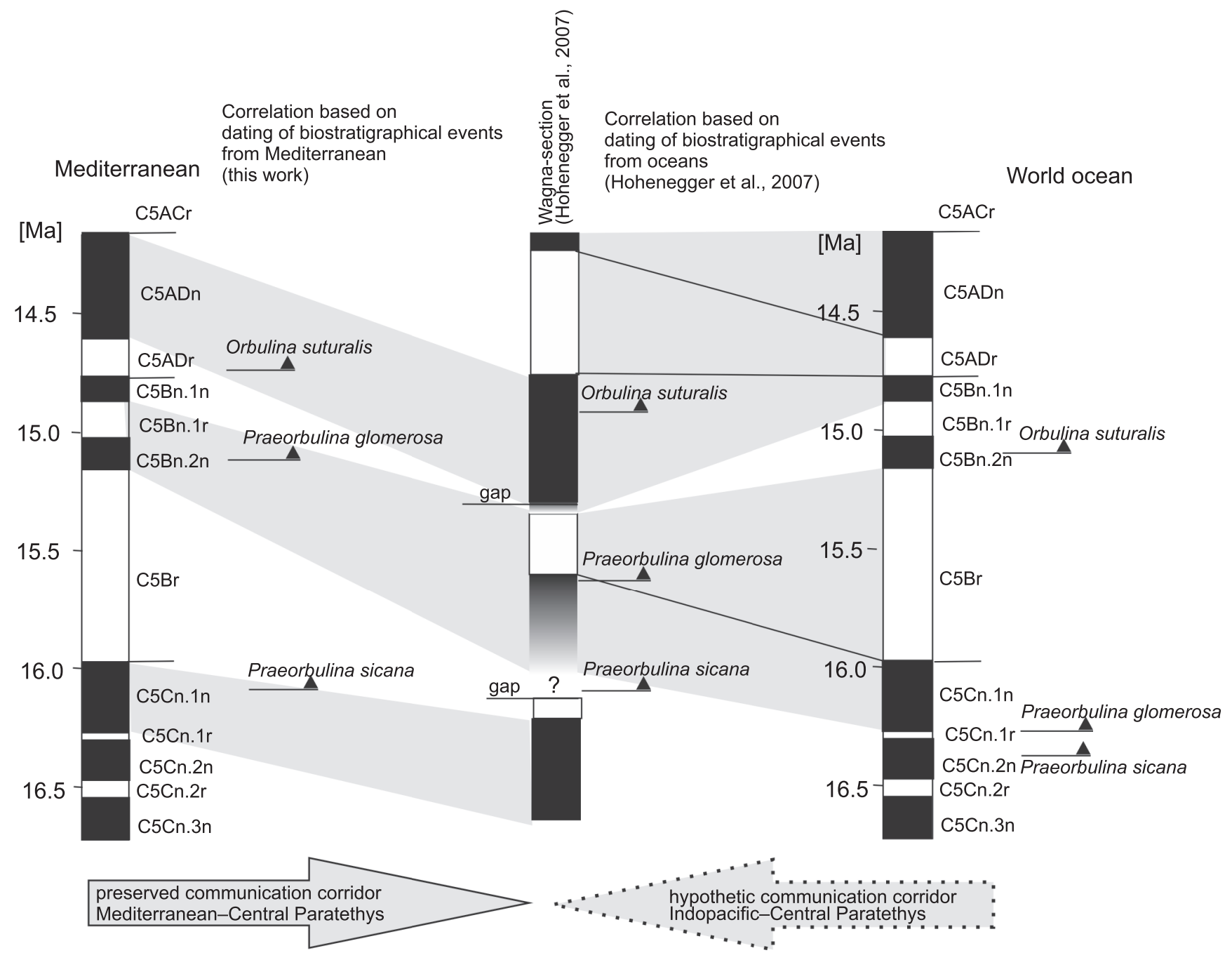

Fig. 3. Correlation of magnetostratigraphical chrons detected in the Central Paratethys (Hohenegger et al., 2009a) with a global magnetostratigraphical chart based on the FOs of index taxa in the world oceans and the Mediterranean

have led via the Central Paratethys and the Transylvanian and Pannonian basins further eastwards to the southern margin of the Black Sea plate and the Pontids (Rögl, 1998; Fig. 4). However, possible evidence for this marine pathway was destroyed during subduction of oceanic crust in the Alpine-Himalayan orogenic belt.

For the reasons described above, we prefer use of the Mediterranean bioevent dating for calibration of magnetostratigraphical chrons detected by Hohenegger et al. (2009a). The FO of $P$. glomerosa in the world ocean dated at 16.4-16.1 Ma (Wade et al., 2011) corresponds to C5Cn.1n chron (16.29-15.97 Ma; Gradstein et al., 2012). If the normal polarity chron with the FO of $P$. glomerosa in the Styrian Basin (Hohenegger et al., 2009a) is correlated with the Mediterranean datum of the FO of the same taxon (15.2-15.1 Ma; di Stefano et al., 2008, laccarino et al., 2011), chron C5Bn.2n (15.15-15.04 Ma; Gradstein et al., 2012) may be inferred (Figs. 3 and 4). Similarly, the reverse polarity chron with the FO of $P$. sicana can be interpreted ambiguously based on a heterochronous timing of the FO of $P$. sicana in the world oceans (16.97 Ma based on Gradstein et al., 2012 or $16.4 \mathrm{Ma}$ from Wade et al., 2011) and in the Mediterranean (16.177 Ma; laccarino et al., 2011; Turco et al., 2011). If the Mediterranean age is accepted, the species would appear in the Central Paratethys in the earliest Langhian $\mathrm{C} 5 \mathrm{Br}$ Chron
(15.974-15.16 Ma) rather than in the latest Burdigalian Chron C5Cn.1r (16.3 Ma; Gradstein et al., 2012; Figs. 3 and 4). Moreover, praeorbulinas occurred only discontinuously in the sections studied, in which case, determination of their exact FOs may be misleading and their occurrence can be used only for approximate dating of strata with $P$. sicana at $\sim 15.9-15.1 \mathrm{Ma}$ and with $P$. glomerosa from 15.1 to $14.6 \mathrm{Ma}$.

Deposits with rare Praerbulina sicana and $P$. glomerosa appear to be restricted to the Central Paratethys. However, it is not exactly known to what extent they represent the original marine transgression. The occurrence of redeposited mudstone intraclasts with the Langhian microfossils in deposits of the second Badenian cycle indicates that it may have been reduced by subsequent erosion. On the other hand, they may have not been recognized in some areas due to a lack of rare praeorbulinas. Additional numerical dating would certainly help to resolve these questions.

The first occurrences of Helicosphaera waltrans, Praeorbulina circularis and Orbulina suturalis. The FOs of Praeorbulina circularis, Orbulina suturalis and Helicosphaera waltrans represent important bioevents recognized over the Central Paratethys. However, their succession may spatially and temporally vary or be absent in individual Central Paratethys basins (Fig. 5): O. suturalis with $H$. waltrans frequently appear simultaneously in the CF in Ukraine and in the 


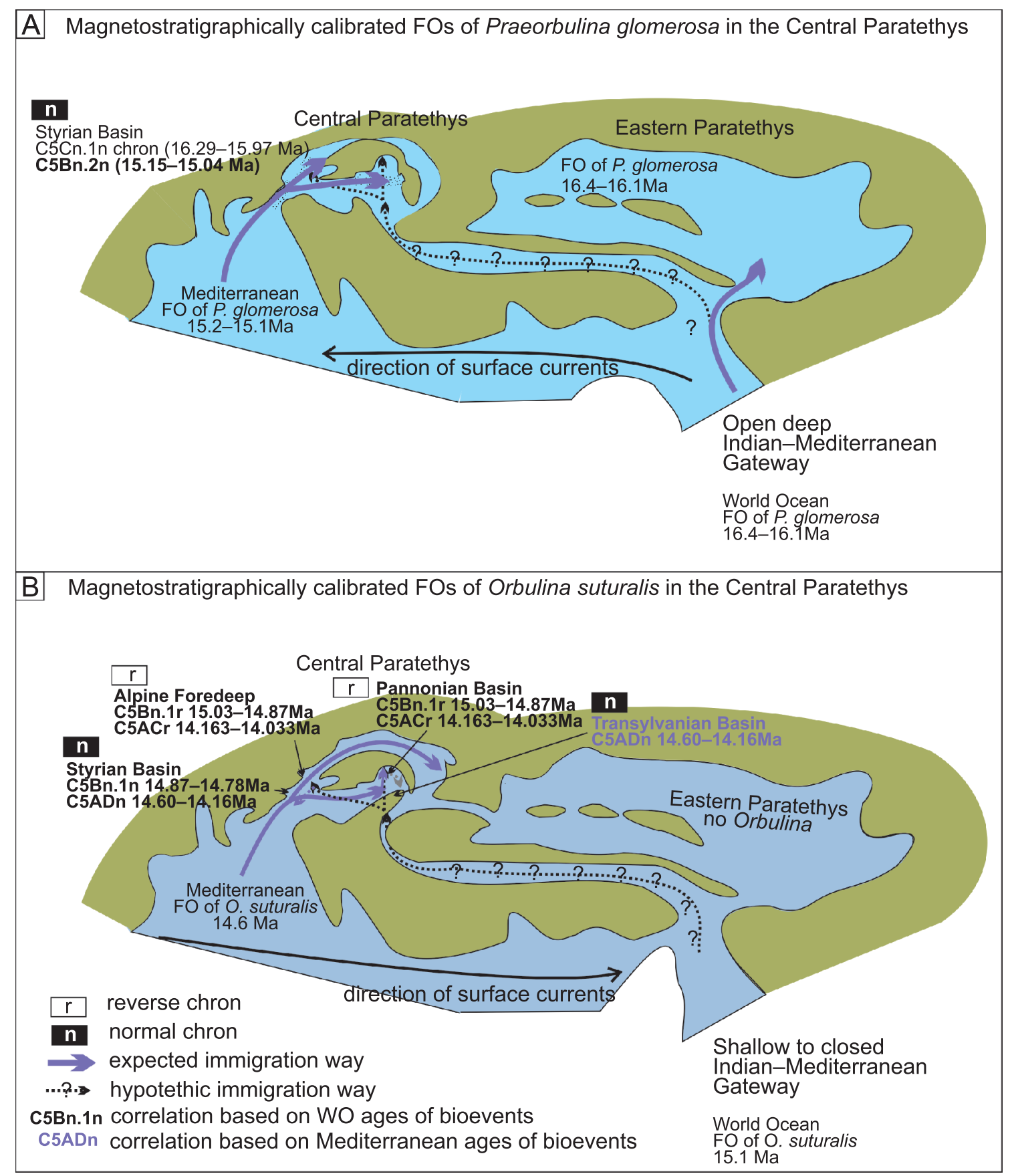

Fig. 4. Magnetostratigraphically calibrated FOs of Orbulina in the Central Paratethys (based on data of Ćorić et al., 2004; Hohenegger et al., 2009a; de Leeuw, 2011; Selmeczi et al., 2012) with possible immigration pathways (palaeogeographic reconstruction modified from Rögl, 1998 and Kováč et al., 2017a)

North Croatian Basin, while praeorbulinas do not occur here (Ćorić et al., 2009; Gozhyk et al., 2015). A H. waltrans occurrence without orbulinas has been reported from the Eastern Paratethys (Gozhyk et al., 2015). Orbulinas without $H$. waltrans were described from the northern part of the Danube Basin (Rybár et al., 2015).

The FO of Orbulina suturalis often coincides with the FOs of other praeorbulinas, primarily P. circularis. However, in the Styrian Basin, the Alpine Foredeep Basin and the CF, the FO of $P$. circularis slightly preceded the $\mathrm{FO}$ of $O$. suturalis (Cicha et al., 1975; Ćorić et al., 2004; Spezzaferri et al., 2009; Doláková et al., 2014; Fig. 5).

Orbulinas are the most widely distributed index microfossils in this time interval, which occur in all Central Paratethys basins (e.g., Ćorić et al., 2004, 2009; Tomanová-Petrová and Švábenická, 2007; Spezzaferri et al., 2009; Selmeczi et al., 2012; de Leeuw et al., 2013; Peryt, 2013; Doláková et al., 2014; Holcová et al., 2015a, b; Gozhyk et al., 2015; Rybár et al., 2015). The FO of Orbulina represents the base of the local biozone of Praeorbulina-Orbulina suturalis (Cicha et al., 1975). 
The magnetostratigraphical timing of the O. suturalis FO differs in individual basins (Fig. 4). In the Transylvanian Basin it is calibrated at 14.6-14.17 Ma, which corresponds to the C5ADn Chron (de Leeuw, 2011). This is consistent with the Mediterranean dating (14.59 Ma; di Stefano et al., 2008; Figs. 3 and 4). In other basins, world-ocean bioevent ages for calibration of detected magnetostratigraphical chrons were used. In the Pannonian Basin, it appeared in the reverse chron correlated with C5Bn.1r Chron (15.03-14.87 Ma; Selmeczi et al., 2012). A similar age is suggested for the Alpine Foredeep Basin (Ćorić et al., 2004), while the species' first occurrence in the Styrian Basin is dated to the normal Zone C5Bn.1n (14.87-14.78 Ma). In the case of Mediterranean bioevents dating, detected magnetochrons can be re-calibrated to the C5ADn Chron as in the Transylvania Basin. This calibration can be also supported by radiometric dating of horizons close to the $\mathrm{FO}$ of Orbulina in Retznei Quarry: 14.21 and 14.39 Ma (Handler et al., 2006). Reverse chrons in the Alpine Foredeep and Pannonian basins can be correlated with C5ACr Chron (14.163-14.033 Ma) and may indicate a gradual appearance of Orbulina in the Central Paratethys from the south to the north.

The first occurrences of Helicosphaera waltrans and the last occurrences of Helicosphaera ampliaperta. Generally, last occurrences have limited correlation potential in epicontinental seas due to the effect of specific palaeoenvironments, which may locally accelerate or delay species extinction. Reworking of microfossils may commonly occur here. This may explain variable relative positions of the LO of Helicosphaera ampliaperta in comparison to other events (Fig. 5). In the world oceans and the Central Paratethys this event occurred after the FO of $P$. glomerosa. By contrast, a reverse bioevent succession can be traced in the Mediterranean.

The Mediterranean species Helicosphaera waltrans appeared in the Central Paratethys above the FO of $P$. glomerosa, simultaneously with the LO of $H$. ampliaperta (Ćorić et al., 2004; Bartol, 2009) or slightly later (Spezzaferri et al., 2009). The co-occurrence of both helicosphaeras (Švábenická, 2002) may reflect either specific conditions in the CF enabling co-occurrence of both species or redeposition of $H$. ampliaperta from older strata. The LOs of $H$. ampliaperta may be correlated with the LOs of other large helicosphaeras (H. scissura, H. mediterranea; Švábenická, 2002) which supports the first possibility.

However, both events have limited applicability in biostratigraphy: the $\mathrm{FO}$ of $\mathrm{H}$. waltrans due to its scarcity and the LO of $H$. ampliaperta due to its possible reworking.

Last common occurrence of Helicosphaera waltrans. The timing of this easily recognizable event can be approximated from dating of the Sooss borehole (Vienna Basin) at 14.38-14.14 Ma (Hohenegger et al., 2009b). H. waltrans was not recorded in this borehole. In the Styrian Basin $H$. waltrans was recorded in a radiometrically dated horizon (14.39 Ma; Hohenegger et al., 2009a). This dating indicates that the event occurred at $14.39-14.38 \mathrm{Ma}$, in accordance with the Mediterranean dating of this event (14.357 Ma, Abdul-Azis et al., 2008; 14.414 Ma, Hüsing et al., 2010).

The last occurrence of Sphenolithus heteromorphus. The LO of S. heteromorphus is a significant event in the Mediterranean (Hilgen et al., 2009) which is, however, poorly recognized in the Central Paratethys. Its stratigraphic range may be reduced in some basins (e.g., the northern part of the Danube Basin; Rybár et al., 2015).

Local bioevents. Local bioevents (acme of Reticulofenestra minuta, Spiroplectinella carinata, Globorotalia transylvanicaand miliolids) can only be traced in the Central Paratethys. These events probably reflected specific local palaeoenvironments.

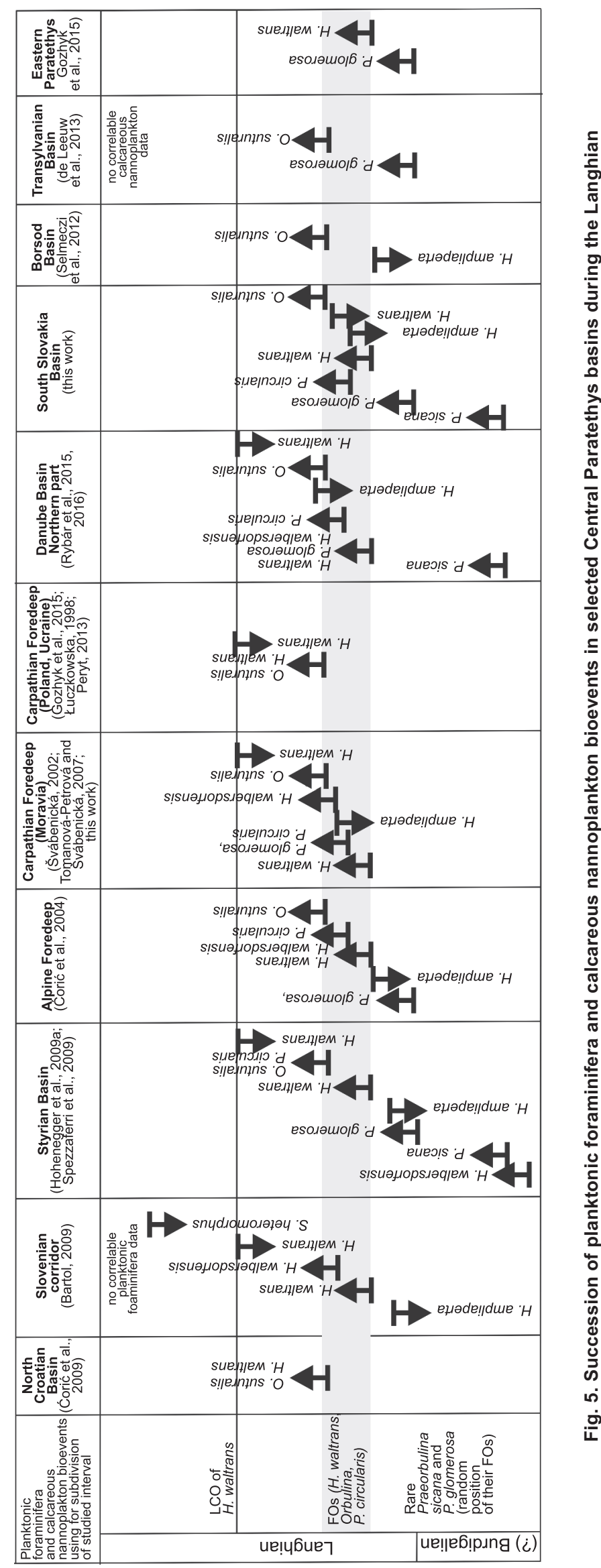




\section{CLIMATOSTRATIGRAPHIC AND SEQUENCE} STRATIGRAPHIC CORRELATION

Climatostratigraphy. The very low abundance of arctotertiary markers and high number of thermophylous elements in the interval with the first praeorbulinas can be correlated with the peak of the Middle Miocene Climatic Optimum (MMCO; 15 Ma; Gradstein et al., 2012). Increased abundances of xerophytic markers in the same interval correspond with the first Mediterranean aridification event dated at 15.074 Ma (Hüsing et al., 2010). These ages fit well to the calibration of magnetostratigraphical chrons using the Mediterranean bioevent dating.

Subsequent increase in abundance of arctotertiary markers indicates climate cooling around the FO of Orbulina; increased humidity can be inferred from a decrease in xerophytic markers. This change is followed by gradual cooling (increased abundance of arctotertiary markers) and aridification (increased xerophytic markers), which corresponds to the Mi-3a cooling event (14.3 Ma; Gradstein et al., 2012) and more distinctive Mi-3b event (13.8 Ma; Gradstein et al., 2012).

Sequence stratigraphy. Two depositional cycles have been identified within the Moravian sequence of the CF. The first cycle, correlated with TB2.3 of Haq et al. (1987), dates to the pre-Middle Badenian (Hohenegger et al., 2014). The second one, widely recognizable in the Paratethys Province (TB2.4; Haq et al., 1987), corresponds to the Middle Badenian (Hohenegger et al., 2014). Deposits of the first depositional cycle have been penetrated in boreholes in the Alpine-Carpathian Foredeep (Ćorić and Rögl, 2004). Although they have not been recognized in the outcrops and shallow boreholes we studied, their regional occurrence can be supported by the common presence of mudstone intraclasts (Eggenburgian to Early Badenian in age; Nehyba et al., 2006) redeposited in "the coarse-grained basal Badenian clastics" (Nehyba et al., 2008). They are interpreted as coarse-grained deltaic system deposits (Nehyba et al., 2008).

The second Badenian depositional cycle is mostly represented by outer shelf deposits or hemipelagites. These deposits volumetrically predominate in the part of the CF studied. They can also be found further westwards as scattered erosional relicts documenting the original extent of these deposits (Hladilová et al., 1999; Holcová et al., 2015a; Nehyba et al., 2016).

\section{EARLY BADENIAN PALAEOENVIRONMENT AND ITS INFLUENCE ON BIOEVENT TIMING}

Several key factors influenced the distribution of index taxa in the Central Paratethys: (1) the quality of the Central Paratethys water-masses (i.e., temperature, salinity, nutrient and oxygen content) played a role in the successful survival and reproduction of index taxa; (2) the circulation regime primarily in the Mediterranean-Paratethys system (estuarine vs antiestuarine, see Fig. 6). The anti-estuarine regime may have triggered plankton immigration, while predominantly estuarine circulation may have had the opposite effect; (3) the existence, character (mainly depth) and water quality of communication corridors. Generally, the greater the depths of the communication pathway, the lesser the effect of climate, presence of other corridors or current regime on plankton exchange (this principally applies for depths $>1,000 \mathrm{~m}$ ). In shallower corridors $(<200 \mathrm{~m})$, exchange with the adjacent oceans may be highly sensitive to the above-mentioned factors (Vara, 2015). Since the latter arrangement is expected in our study area, the previously described factors must be taken into consideration.

For interpretation of circulation regime, sea-water stratification may be significant. The stratification was reconstructed from stable oxygen isotope data for the interval above the FO of Orbulina. The foraminifera tests from the interval below the FO of Orbulina were poorly preserved. The interval between the FO of Orbulina and the LCO of Helicosphaera waltrans is characterized by significant differences in surface and bottom water oxygen isotope values (Fig. 2E, F), which may indicate the presence of a well-stratified water column. Seasonal variations in isotope values between spring and summer can also be seen (Fig. 2E, F). This variation is less pronounced above the LCO of Helicosphaera waltrans, and can be interpreted as a result of mixing of surface and bottom waters during the spring plankton bloom and increased salinity/temperature variability in summer.

In the following chapter we discuss migration pathways and restrictions of new organisms in the three stratigraphic intervals distinguished.

Interval with Praeorbulina sicana and $P$. glomerosa dominated by estuarine circulation (15.9-14.3 Ma). The corridor between the Atlantic and the Mediterranean remained relatively deep during the Early Langhian, which enabled entry of cold Atlantic water as shown by the occurrence of psychrospheric ostracods (Benson, 1978). The palaeobiological evidence can be supported by carbon isotope data (VergnaudGrazzini, 1983, 1985), which demonstrates identical isotope composition in the Atlantic and western Mediterranean bottom waters. Central Mediterranean estuarine circulation is suggested for the Early Langhian up to the FO of Orbulina (upper part of the $P$. sicana Subzone, i.e. middle part of the MNN5a Subzone; Dall'Antonia et al., 2001). The Indo-Pacific connection remained open with the Circumequatorial Current in place (von der Heydt and Dijkstra, 2005) in the time interval prior to the FO of Orbulina (Gebhardt, 1999). The presence of diatoms, high-nutrient Globigerina and Coccolithus pelagicus and high-nutrient benthic foraminiferal taxa may also indicate an estuarine circulation in the Central Paratethys (Tomanová-Petrová and Švábenická, 2007).

The rare occurrence of Praeorbulina sicana and $P$. glomerosa in the Central Paratethys may be related to prevailing estuarine circulation and restricted plankton immigration (Fig. 6). Another factor that limited Praeorbulina occurrence in the Central Paratethys may be the lack of a suitable palaeoenvironment for this plankton group. Both Orbulina, and Praeorbulina thrived in stratified oceans with a summer warm water layer in place (Chapman and Davis, 2010). This can be evidenced by the identical isotopic composition of both groups in our study material (Scheiner, 2015). This warm surface water layer was probably absent in the Central Paratethys during the Early Badenian, which can also be documented by the rare occurrence of other warm-water elements as Globigerinoides or Globigerinella. Helicosphaera ampliaperta and $H$. waltrans co-occurrence in the Central Paratethys in contrast to the Mediterranean also indicates a different quality of surface waters in both regions. The earlier disappearance of $H$. ampliaperta in the Mediterranean at $\sim 15.5 \mathrm{Ma}$ (laccarino et al., 2011) may have accelerated the evolution of Helicosphaera waltrans in a Mediterranean vacant niche.

The MMCO at $\sim 15 \mathrm{Ma}$ can be correlated with this interval (Zachos et al., 2001; Gradstein et al., 2012). However, studies on microflora and macroflora from the Pannonian and Vienna basins showed some differences to the global trends over the Early and Middle Miocene. The Early Langhian temperature peak does not represent the Miocene temperature maximum in 


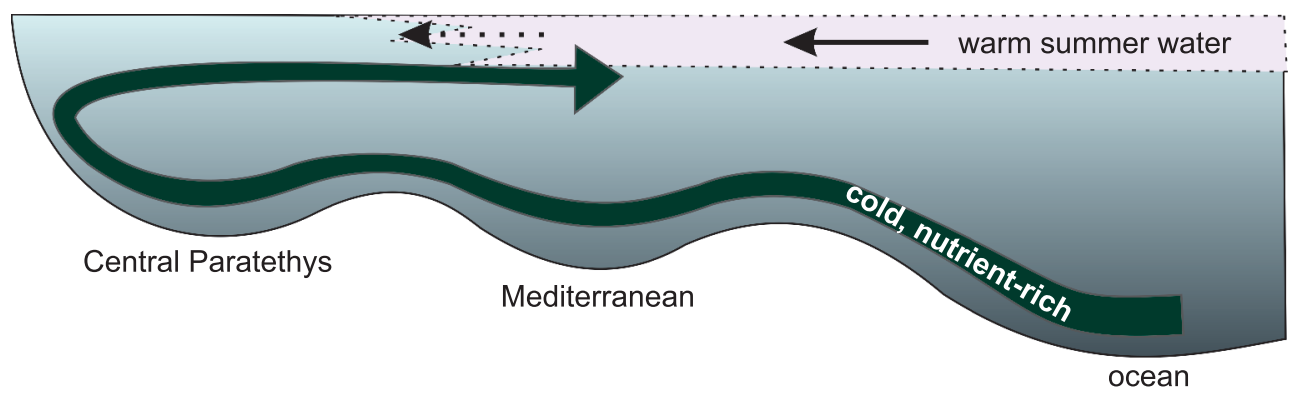

Interval with Praeorbulina circularis, Orbulina suturalis and Helicosphaera waltrans: transition from estuarine to anti-estuarine circulation (14.6-14.3 Ma)

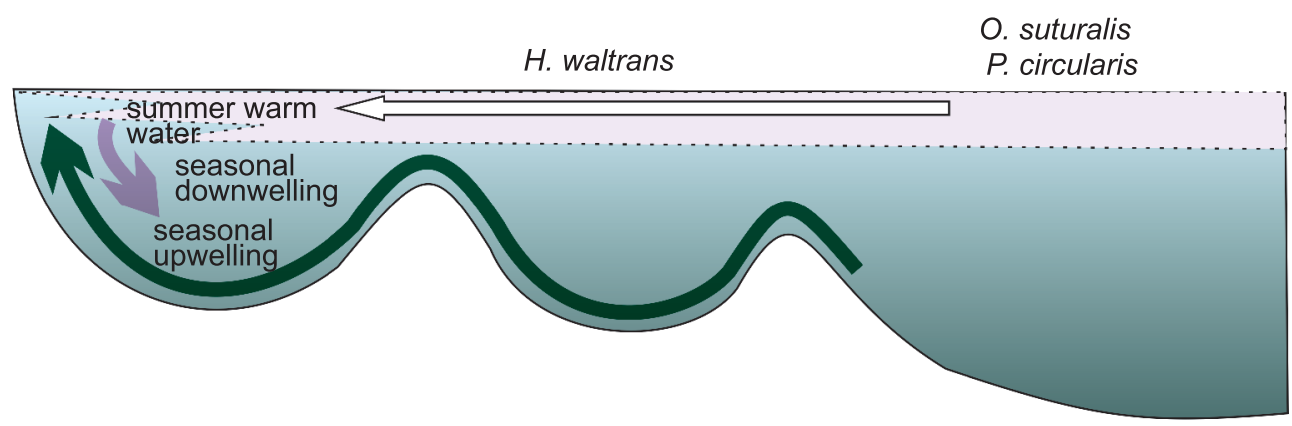

Interval with Orbulina suturalis and common $H$. walbersdorfensis: anti-estuarine circulation (14.3-13.8 Ma)

Helicosphaera walbersdorfensis

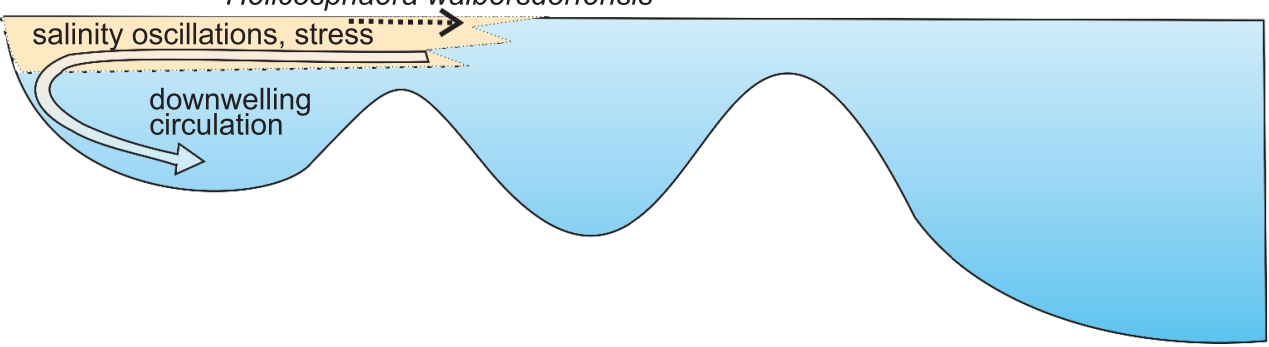

Fig. 6. Models of immigration of biostratigraphical index planktonic foraminifera and calcareous nannoplankton to the Central Paratethys during the Early Badenian (Langhian)

the study area. The warmest climate was recorded in the Eggenburgian-Ottnangian transition ( 17-16 Ma; Knobloch et al., 1975; Planderová, 1990; Jiménez-Moreno et al., 2005, 2006; Kvaček et al., 2006; Doláková et al., 2011a, b; Kováčová et al., 2011; Doláková et al., 2014). This corresponds to the conclusions of Böhme et al. (2007), who described the succession from paratropical evergreen forest between 17.5-17.3 Ma, followed by subtropical semi-deciduous and oak-laurel subtropical forest (17-15.3 Ma) from the North Alpine Foredeep xyloflora. This probably reflects mesoclimatic changes caused by northerly plate tectonic shift and/or uplift of the Carpathian mountain chain.

Transition from estuarine to anti-estuarine circulation in the interval with Praeorbulina circularis, Orbulina suturalis and Helicosphaera waltrans (14.6-14.3 Ma). Closure of the Indian Gateway in the Middle Langhian caused a transition from estuarine to anti-estuarine circulation in the proto-Mediterranean (Kouwenhoven, 2000). This can be dated to the time interval between the FO of $O$. suturalis and the $\mathrm{FO}$ of
O. universa (Russo et al., 2007) at 14.56-14.36 Ma (di Stefano et al., 2008). Change in the Mediterranean circulation regime also influenced circulation changes along the Mediterranean-Central Paratethys communication gateway and triggered several distinct bioevents (i.e., FOs of Praeorbulina circularis, Orbulina suturalis and Helicosphaera waltrans over a short period of time which coincides with the drop in the Coccolithus pelagicus/Reticulofenestra minuta ratio; Tomanová-Petrová and Švábenická, 2007; Spezzaferri at al., 2009). This is interpreted as a result of variations in surface water quality. C. pelagicus is an indicator of cold and nutrient-rich waters (Okada and McIntyre, 1979; Winter et al., 1994; Cachao and Moita, 2000), which is consistent with the estuarine circulations in the Early Langhian. On the other hand, the occurrence of $R$. minuta indicates environmental stress characterized by salinity and nutrient oscillations (Flores et al., 1997; Wells and Okada, 1997; Kameo, 2002; Wade and Brown, 2006). Deteriorating quality of surface waters may be linked to salinity oscillations in a downwelling circulation regime expanding from the 
Mediterranean to the Paratethys. Our detailed analysis shows that the interval with $H$. waltrans represents a transition between both regimes with locally persisting coastal upwelling (Holcová et al., 2015a). Generally, this newly established anti-estuarine circulation triggered the formation of a warm summer surface water layer and the immigration of planktonic taxa such as orbulinas and praeorbulinas and also Globigerinoides spp. and Globigerinella regularis (Fig. 6; Holcová et al., 2015a).

The variegated succession of the FOs of Praeorbulina circularis, Orbulina suturalis and Helicosphaera waltrans and the position of the FO of Orbulina in normal and reverse magnetochrons suggests that the second Badenian transgression was not isochronous across different basins. This effect is generally recognized in peripheral foreland basins as the formation of accommodation space in distal and proximal parts (Heller et al., 1988; Catuneanu et al., 1997, 1998).

Interval with Orbulina suturalis and common $\boldsymbol{H}$. walbersdorfensis dominated by anti-estuarine circulation and onset of the Wielician salinity crisis (14.3-13.8 Ma). No global bioevent has been recognized in the Central Paratethys during this interval. A local event characterized by a gradual substitution of large $H$. waltrans by small $H$. walbersdorfensis occurred at its base. The relative abundance of $H$. walbersdorfensis positively correlated with Reticulofenestra minuta (Holcová, 2017) suggests its stress-tolerance. The palaeoenvironmental changes during this event were summarized by Doláková et al. (2014), Holcová et al. (2015a, b), and Nehyba et al. (2016), being characterized by increasing aridity and decreasing riverine and terrestrial nutrient input with episodic heavy rainfalls. Increased seasonality caused perturbations in mixed and stratified water columns and seasonal variations in nutrient input. Increase in the surface water salinity during summers can be detected in the oxygen isotope record (Scheiner, 2015) and dinoflagellate assemblages (Nehyba et al., 2016). Aridification trends can also be traced in the increased percentage of xerophytic markers in the pollen spectra from our studied boreholes (Fig. 2C). A similar trend dated at 14.3 Ma was described by Böhme et al. (2010) from xyloflora of the Alpine Foredeep Basin.

The timing at $\sim 14.3 \mathrm{Ma}$ can also be approximated to the FCO of $H$. walbersdorfensis. The age of its FCO in the Mediterranean (14.05 Ma; Mourik et al., 2011) indicates the immigration direction from the Paratethys to the Mediterranean, which is expressed in the bioevents succession. The stress-tolerant $H$. walbersdorfensis, a typical Paratethyan species, reflected a varying quality of surface water in a small epicontinental basin which extended to the Mediterranean due to the Middle Miocene Climatic Transition, while closure of the Indian-Mediterranean Gateway and a change in the circulation pattern also occurred in the Atlantic-Mediterranean Gateway at the end of the Langhian (Gebhardt, 1999).

This interval is characterized by a dominance of conifers in the pollen spectra, which is sometimes referred to as the Pinus event. The accumulation of conifer pollen in offshore marine sediments may be explained by pollen mass production, long-distance aerial transport (from W or NW) and also by their high resistance to oxidation in water or sediment (Heusser, 1978; Hopkins and McCarthy, 2002). A cyclic arrangement of this mass accumulation is consistent with variations in abundance of biserial agglutinated foraminifera and Globorotalia transylvanica/bykovae and also with multiproxy cyclicity in the Sooss borehole (Vienna Basin), interpreted as Milankovitch climatic cycles (Hohenegger et al., 2008).
The interval was terminated by the Wielician salinity event that led to increased salinity of the surface water layer (Scheiner, 2015; Nehyba et al., 2016). This can be documented by an increase in miliolid abundance in the shallow-water deposits. This bioevent is dated at $13.73 \mathrm{Ma}$ in the Danube Basin (Fordinál et al., 2014) which is consistent with dating of the salinity crisis (beginning at 13.81 Ma with a duration between 200 and 600 ky; de Leeuw et al., 2010).

Although the persistant anti-estuarine circulation should generally favour the immigration of biostratigraphic plankton markers to the Central Paratethys (the FO of G. praemenardi at $14.4 \mathrm{Ma}$ in the world oceans or $13.9 \mathrm{Ma}$ in the Mediterranean; Gradstein et al., 2012), the cooling (recorded in micro- and macroflora) and salinity oscillations in the surface waters probably restricted this process. The salinity crisis started prior to the LO of $S$. heteromorphus in the world oceans (13.5 Ma; Gradstein et al., 2012), which suggests that the bioevent occurred earlier in the Central Paratethys due to oscillating salinity.

Salinity oscillations accompanied by salt deposition can be detected all over the Mediterranean region (evaporite deposits in Egypt; led et al., 2011) and may be used as a correlation horizon in sequences with no index taxa.

The cooling event can be detected slightly later in the continental plant assemblages (at $\sim 13.5 \mathrm{Ma}$; Planderová, 1990; Jiménez-Moreno et al., 2005; Jiménez-Moreno, 2006; Kvaček et al., 2006; Doláková et al., 2011, 2014; Kováčová et al., 2011). This disproportion has not yet been adequately explained.

\section{CONCLUSIONS}

1. The interval between the FO of Praeorbulina and the FO of $H$. waltrans and/or Orbulina correlates with the first Badenian transgression. Probably only the Mediterranean-Central Paratethys Gateway was in place at this time with no direct connection between the Central Paratethys and the world ocean. Therefore, the timing of biostratigraphical events recorded here must be coeval with or later than in the Mediterranean. In this case, correlation of the Karpatian/Badenian boundary with the Burdigalian/Langhian boundary (in the sense of Piller et al., 2007) is appropriate, and can be corroborated by climatostratigraphic data placing the top of the MMCO to this interval.

The first Badenian biostratigraphical markers (Praeorbulina sicana and $P$. glomerosa) were only rarely detected in the Central Paratethys. This is interpreted as a consequence of restricted immigration of the index taxa linked to the absence of a warm surface water layer in this region and predominantly estuarine circulation in the Mediterranean-Paratethys system. The scarcity or absence of standard biostratigraphical markers and/or presence of numerous gaps related to tectonic uplift complicate stratigraphic correlation in this interval, and more radiometric ages would certainly help understanding of this period.

2. The coeval FOs of Praeorbulina circularis, Orbulina suturalis and Helicosphaera waltrans at the base of the second Badenian transgressive cycle coincide with the change from estuarine to anti-estuarine circulation regime in the Mediterranean-Paratethys system. This was accompanied by establishment of a warm summer surface water layer in the Central Paratethys. Slightly different bioevent timings and their succession may indicate heterochrony of the transgression in individual basins and the formation of a summer surface water layer.

3. The Middle Miocene climatic transition significantly affected the Central Paratethys palaeoenvironment in the time in- 
terval following the LCO of Helicosphaera waltrans. This resulted in climatic instability, and climate cooling followed by a regional salinity crisis. Its onset can be detected earlier in marine settings and later in continental environments. The absence of standard stratigraphical markers can be related to palaeoenvironmental fluctuations and salinity oscillations.
Acknowledgements. The study was supported by the projects PROGRES Q45, Ministry of Culture programme DKRVO 2016/04 (National Museum, 00023272). The authors greatly appreciate the constructive reviews of $D$. Peryt and M. Oszczypko-Clowes which improved the manuscript.

\section{REFERENCES}

Abdul Aziz, H.A., Di Stefano, L.M., Foresi, F.J., Hilgen, S.M., laccarino, K.F., Kuiper, F., Lirer, G., Salvatorini, A., Turco, E., 2008. Integrated stratigraphy and ${ }^{40} \mathrm{Ar} /{ }^{39} \mathrm{Ar}$ chronology of early Middle Miocene sediments from DSDP Leg 42A, Site 372 (Western Mediterranean). Palaeogeography, Palaeoclimatology, Palaeoecology, 257: 123-138.

Bartol, M., 2009. Middle Miocene calcareous nannoplankton of NE Slovenia (western Central Paratethys). Založba ZRC/ZRC Publishing, Ljubljana.

Basistová, P., Doláková, N., 2011. Palynological evaluation of the sediments from borehole Iváň IK-1 near Hustopeče. Palynologické zhodnocení sedimentů z vrtu Iváň IK-1 u Hustopečí. Geologické výzkumy na Moravě a ve Slezsku: 35-39.

Benson, R.H., 1978. The paleoecology of the Ostracodes of DSDP Leg 42-A. Initial Reports Deep Sea Drilling Project, 42: 777-787.

Böhme, M., Bruch, A.A., Selmeier, A., 2007. The reconstruction of Early and Middle Miocene climate and vegetation in Southern Germany as determined from the fossil wood flora. Palaeogeography, Palaeoclimatology, Palaeoecology, 253: 91-114.

Böhme, M., Winklhofer, M., Ilg, A., 2010. Miocene precipitation in Europe: temporal trends and spatial gradients. Palaeogeography, Palaeoclimatology, Palaeoecology, 304: 212-218.

Brzobohatý, R., Cicha I., 1993. Karpatská předhlubeň (in Czech). In: Geologie Moravy a Slezska (eds. A. Přichystal, V. Obstová and M. Suk):123-128. MZM a PřF MU Brno.

Cachao, M., Moita, M.T., 2000. Coccolithus pelagicus, a productivity proxy related to moderate fronts off Western Iberia. Marine Micropaleontology, 39: 131-155.

Caralp, M.H., 1989. Abundance of Bulimina exilis and Melonis barleeanum: relationship to the quality of marine organic matter. Geo-Marine Letters, 9: 37-43.

Catuneanu, O., Beaumont, C., Waschbusch, P., 1997. Interplay of static loads and subduction dynamics in foreland basins: reciprocal stratigraphies and the 'missing' peripheral bulge. Geology, 25: $1087-1090$

Catuneanu, O., Hancox, P.J., Rubidge, B.S., 1998. Reciprocal flexural behaviour and contrasting stratigraphies: a new basin development model for the Karoo retroarc foreland system, South Africa. Basin Research, 10: 417-439.

Chapman, D.S., Davis, M.G., 2010. Climate Change: past, present and future. Eos Transactions American Geophysical Union, 91: 325-326.

Cicha, I. 2001. Outline of the stratigraphy of the Middle Miocene in the Alpine-Carpathian Foredeep (Lower Austria, Moravia). Scripta Facultatis Scientiarum Naturalium Universitatis Masarykianae Brunensis, Geology, 30: 23-26.

Cicha, I., Čtyroká, J., Jiříček, R., Zapletalová, I., 1975. Principal biozones of the Late Tertiary in Eastern Alps and West Carpathians. In: Biozonal division of the Upper Tertiary Basins of the Eastern Alps and West-Carpathians (ed. I. Cicha): 19-34. IUGS, Proceeding of the VI. Congress, Bratislava.

Ćorić, S., Rögl, F., 2004. Roggendorf-1 borehole, a key-section for Lower Badenian transgressions and the stratigraphic position of the Grund Formation (Molasse Basin, Lower Austria). Geologica Carpathica, 55: 165-178.
Ćorić, S., Harzhauser, M., Hohenegger, J., Mandic, O., Pervesler, P., Roetzel, R., Scholger, R., Spezzaferri, S., Stingl, K., Švábenická, L., Zohrn, I., Zuschin, M., 2004. Stratigraphy and correlation of the Grund Formation (Middle Miocene, Lower Badenian, Austria). Geologica Carpathica, 55: 207-215.

Ćorić, S., Pavelić, D., Rögl, F., Mandic, O., Vrabac, S., Avanić, R., Jerković, L., Vranjković, A., 2009. Revised Middle Miocene datum for initial marine flooding of North Croatian Basins (Pannonian Basin System, Central Paratethys). Geologia Croatica, 62/1: 31-43.

Dall'Antonia, B., Di Stefano, A., Foresi, L.M., 2001. Integrated micropalaeontological study (ostracods and calcareous plankton) of the Langhian western Hyblean succession. Palaeogeography, Palaeocology, Palaeoeclimatology, 176: 59-80.

de Leeuw, A., 2011. Paleomagnetic and geochronologic constraints on the Miocene evolution of semi-isolated basins in southeastern Europe. Ph.D. thesis, Utrecht University, Utrecht, Netherlands.

de Leeuw, A., Bukowski, K., Krijgsman,W., Kuiper, K.F., 2010. Age of the Badenian salinity crisis; impact of Miocene climate variability on the circum-Mediterranean region. Geology, 38: 715-718.

de Leeuw, A., Filipescu, S., Matenco, L., Krijgsman, W., Kuiper, K., Stoica, M., 2013. Paleomagnetic and chronostratigraphic constraints on the Middle to Late Miocene evolution of the Transylvanian Basin (Romania): Implications for Central Paratethys stratigraphy and emplacement of the Tisza-Dacia plate. Global and Planetary Change, 103: 82-98.

di Stefano, A., Foresi, L.M., Lirer, F., laccarino, S.M., Turco, E., Amore, F.O., Morabito, S., Salvatorini, G., Mazzei, R., Abdul Aziz, H., 2008. Calcareous plankton high resolution bio-magnetostratigraphy for the Langhian of the Mediterranean area, 114: $51-76$.

Doláková, N., Hladilová, Š., Nehyba, S., 1999. Development of sedimentation, molluscs and palynospectra in the Lower Miocene of the south-western part of the Carpathian Foredeep in Moravia (Czech Republic). Acta Palaeobotanica, Supplement, 2: 269-278.

Doláková, N., Brzobohatý, R., Hladilová, Š., Nehyba, S., 2008. The red algal facies of the Lower Badenian limestones of the Carpathian Foredeep in Moravia (Czech Republic). Geologica Carpathica, 59: 133-146.

Doláková, N., Kováčová, M., Basistová, P., 2011. Badenian (Langhian-Early Serravallian) palynoflora from the Carpathian Foredeep and Vienna Basin (Czech and Slovak Republics). Acta Musei Nationalis Pragae, Series B - Historia Naturalis, 67: $51-59$.

Doláková, N., Holcová, K., Nehyba, S., Hladilová, Š., Brzobohatý, R., Zágoršek, K., Hrabovský, J., Seko, M., Utescher, T., 2014. The Badenian parastratotype at Židlochovice from the perspective of the multiproxy study. Neues Jahrbuch für Geologie und Paläontologie Abhandlungen, 271: 169-201.

Flores, J.A., Sierro, F.S., Francés, G., Vasquez, A., Zamarreno, I., 1997. The last 100,000 years in the western Mediterranean: sea 
surface water and frontal dynamics as revealed by coccolithophores. Marine Micropaleontology, 29: 351-366.

Fordinál, K., Král', J., Harčová, E., Čech, P., Zielinski, G., Nagy, A., 2014. ${ }^{87} \mathrm{Sr} /{ }^{86} \mathrm{Sr}, \quad \delta^{13} \mathrm{C}$ a $\delta^{18} \mathrm{O}$ vo fosílnych schránkach mäkkýšov z morského, brakického a sladkovodného prostredia terciéru Západných Karpát (in Slovak). Mineralia Slovaca, 46: 23-44.

Gebhardt, H., 1999. Middle to Upper Miocene benthonic foraminiferal palaeoecology of the Tap Marls (Alicante Province, SE Spain) and its palaeoceanographic implications. Palaeogeography, Palaeoclimatology, Palaeoecology, 145: 141-156.

Gozhyk, P., Semenenko, V., Andreeva-Grigorovich, A., Maslun, N., 2015. Stratigraphic chart based on planktonic microfossils. Geologica Carpathica, 66: 235-244.

Gradstein, F.M., Ogg, J.G., Schmitz, M.D., Ogg, G.M., 2012. The Geologic Time Scale 2012, 2 Volume Set. Elsevier, New York.

Grill, R., 1943. Über mikropaläontologische Gliederungsmöglichkeiten im Miozän des Wiener Becken. Mitteilungen des Reichsamts für Bodenforschung, 6: 33-44.

Handler, R., Ebner, F., Neubauer, F., Hermann, S., Bojar, A.-V., Hermann, S., 2006. ${ }^{40} \mathrm{Ar} /{ }^{39} \mathrm{Ar}$ dating of Miocene tuffs from Styrian part of the Pannonian Basin: an attempt to refine the basin stratigraphy. Geologica Carpathica, 57: 483-494.

Haq, B.U., Hardenbol, J., Vail, P.R., 1987. Chronology of fluctuating sea levels since the Triassic. Science, 235: 1156-1167.

Hardenbol, J., Thierry, J., Farley, M.B., Jacquin, Th., de Graciansky, P.-C., Vail, P.R., 1998. Mesozoic and Cenozoic sequence chronostratigraphic framework of European basins. SEPM Special Publications, 60: 3-13.

Heller, P.L., Angevine, C.L., Winslow, N.S., Paola, C., 1988. Two phase stratigraphic model of foreland - basin sequences. Geology, 16: 501-504.

Hemleben, C., Spindler, M., Anderson, O.R., 1989. Modern Planktonic Foraminifera. Springer, New York.

Hermelin, J.O.R., 1992. Variations in the benthic foraminiferal fauna of the Arabian Sea: a response to changes in upwelling intensity? Geological Society Special Publications, 64: 151-166.

Heusser, L., 1978. Spores and pollen in the marine realm. In: Introduction to Marine Micropaleontology (eds. B.U. Haq and A. Boersma): 327-339. Elsevier Science, Amsterdam.

Hilgen, F.J., Abels, H.A., laccarino, S., Krijgsman, W., Raffi, I., Sprovieri, R., Turco, E., Zachariasse, W.J., 2009. The Global Stratotype Section and Point (GSSP) of the Serravallian Stage (Middle Miocene). Episodes, 32: 152-166.

Hladilová, Š., Nehyba, S., Doláková, N., Hladíková, J., 1999. Comparison of some relics of Miocene sediments on the eastern margin of the Bohemian Massif. Geologica Carpathica, 50: 31-33.

Hladilová, Š., Doláková, N., Nehyba, S., Hladíková, J., 2001. Nové výsledky studia spodnobadenských sedimentů a fosilií z některých vrtů v karpatské předhlubni jižně od Brna (in Czech). Geologické výzkumy na Moravě a Slezku: 31-34.

Hohenegger, J., Andersen, N., Báldi, K., Ćorić, S., Pervesler, P., Rupp, C., Wagreich, M., 2008. Paleoenvironment of the Early Badenian (Middle Miocene) in the southern Vienna Basin (Austria) - multivariate analysis of the Baden-Sooss section. Geologica Carpathica, 59: 461-487.

Hohenegger, J., Rögl, F., Coric, S., Pervesler, P., Lirer, F., Roetzel, R., Scholger, R., Stingl, K., 2009a. The Styrian Basin: key to the Middle Miocene (Badenian/Langhian) Central Paratethys transgressions. Austrian Journal of Earth Sciences, 102: 102-132.

Hohenegger, J., Ćorić, S., Khatun, M., Pervesler, P., Rögl, F., Rupp, C., Selge, A., Uchman, A., Wagreich, M., 2009b. Cyclostratigraphic dating in the Lower Badenian(Middle Miocene) of the Vienna Basin (Austria) - the Baden-Sooss core. International Journal of Earth Sciences, 98: 915-930.

Hohenegger, J., Ćorić, S., Wagreich, M., 2014. Timing of the regional Badenian Stage (Middle Miocene, Central Paratethys). Geologica Carpathica, 65: 55-66.

Holcová, K., 2017. Response of epicontinental-sea calcareous nannoplankton and foraminiferal assemblages on global
Oligocene and Miocene climatic oscillations (Oi-2, Mi-1 and Mi-3 events): case study from the West Carpathian segment of the Central Paratethys. Geologica Carpathica, 68: 207-228.

Holcová, K., Demeny, A., 2012. The oxygen and carbon isotopic composition of foramiferal tests like paleoecological proxy in the marginal part of the epicontinental sea (example from the early Badenian (=Langhian) of the Central Paratethys). Geologica Carpathica, 63: 121-137.

Holcová, K., Doláková, N., Vass, D., Zágoršek, K., Zelenka, J., 1996. Foraminifera, Bryozoa, Ostracoda and palynomorphs like indicators of marine environment in the Lower Badenian of Strháre-Trenč graben (South Slovakian Basin) (in Slovak). Mineralia Slovaca, 28: 99-119.

Holcová, K., Brzobohatý, R., Kopecká, J., Nehyba, S., 2015a. Reconstruction of the unusual Middle Miocene (Badenian) palaeoenvironment of the Carpathian Foredeep (Lomnice/Tisnov denudational relict, Czech Republic). Geological Quarterly, 59 (4): 654-678.

Holcová, K., Hrabovský, J., Nehyba, S., Hladilová, Š., Doláková, N., Demeny, A., 2015b. The Langhian (Middle Badenian) carbonate production event in the Moravian part of the Carpathian Foredeep (Central Paratethys): a multiproxy record. Facies, 61: $1-26$.

Hopkins, J.A., Mc Carthy, F.M.G., 2002. Post-depositional palynomorph degradation in Quaternary shelf sediments: a laboratory experiment studying the effects of progressive oxidation. Earth and Planetary Science Letters, 290: 254-269.

Hüsing, S.K., Cascella, A., Hilgen, F.J., Krijgsman, W., Kuiper, K.F., Turco, E., Winson, D., 2010. Astrochronology of the Mediterranean Langhian between 15.29 and 14.17 Ma. Earth and Planetary Science Letters, 290: 254-269.

laccarino, S.M., Di Stefano, A., Foresi, L.M., Turco, E., Baldassini, N., Cascella, A., Da Prato, S., Ferraro, L., Gennari, R., Hilgen, F.J., Lirer, F., Maniscalco, R., Mazzei, R., Riforgiato, F., Russo, B., Sagnotti, L., Salvatorini, G., Speranza, F., Verducci, M., 2011. High-resolution integrated stratigraphy of the upper Burdigalian-lower Langhian in the Mediterranean: the Langhian historical stratotype and new candidate section for defining its GSSP. Stratigraphy, 8: 199-215.

led, I.M., Holcová, K., Abd-Elshafy, E., 2011. Biostratigraphy and paleoecology of the Burdigalian-Serravallian sediments in Wadi Sudr (Gulf of Suez, Egypt): comparison with the Central Paratethys evolution. Geologica Carpathica, 62: 233-249.

Jiménez-Moreno, G., 2006. Progressive substitution of a subtropical forest for a temperate one during the Middle climate cooling in Central Europe according to palynological data from cores Tengelic- 2 and Hidas-53 (Pannonian basin, Hungary). Review of Palaeobotany and Palynology, 142: 1-14.

Jiménez-Moreno, G., Rodríguez-Tovar, F.-J., Pardo-Igúzquiza, E., Fauquette, S., Suc, J.-P., Müller, P., 2005. High-resolution palynological analysis in late early-middle Miocene core from the Pannonian Basin, Hungary, climatic changes, astronomical forcing and eustatic fluctuations in the Central Paratethys. Palaeogeography, Palaeoclimatology, Palaeoecology, 216: 73-97.

Kaiho, K., 1994. Benthic foraminiferal dissolved-oxygen index and dissolved oxygen levels in the modern ocean. Geology, 22: 719-722.

Kameo, K., 2002. Late Pliocene Caribbean surface water dynamics and climatic changes based on calcareous nannofossil records. Palaeogeography, Palaeoclimatology, Palaeoecology, 179: 211-226.

Knobloch, E., Bůžek, Č., Holý, F., Kvaček, Z., Němejc, F., 1975. Significant megafloral assemblages in Neogene of Central Europe. In: Biozonal Division of the Upper Tertiary Basins of the Eastern Alps and Western Carpathians (ed. I. Cicha): 87-100. Geological Survey, Prague.

Kopecká, J., 2012. Foraminifera as environmental proxies of the Middle Miocene (Early Badenian) sediments of the Central Depression (Central Paratethys, Moravian part of the Carpathian Foredeep). Bulletin of Geosciences, 87: 431-442. 
Kouwenhoven, T.J., 2000. Survival under stress: benthic foraminiferal patterns and Cenozoic biotic crises. Geologica Ultraiectina, 186: 1-206.

Kováč, M., Baráth, I., Harzhauser, M., Hlavatý, I., Hudáčková, N., 2004. Miocene depositional systems and sequence stratigraphy of the Vienna Basin. Courier Forschungsinstitut Senckenberg, 246: 187-212.

Kováč, M., Andreyeva-Grigorovich, A., Bajraktarević, Z., Brzobohatý, R., Filipescu, S., Fodor, L., Harzhauser, M., Nagymarosy, A., Oszczypko, N., Pavelić, D., Rögl, F., Saftić, B., Sliva, L'., Studencka, B., 2007. Badenian evolution of the Central Paratethys Sea: paleogeography, climate and eustatic sea-level changes. Geologica Carpathica, 58: 579-606.

Kováč, M., Hudáčková, N., Halásová, E., Kováčová, M., Holcová, K., Oszczypko-Clowes, M., Báldi, K., Less, G., Nagymarosy, A., Ruman, A., Klučiar, T., Jamrich, M., 2017a. The Central Paratethys palaeoceanography: a water circulation model based on microfossil proxies, climate, and changes of depositional environment. Acta Geologica Slovaca, 9: 75-114.

Kováč, M., Márton, E., Oszczypko, N., Vojtko, R., Hók, J., Králiková, S., Plašienka, D., Klučiar, T., Hudáčková, N., Oszczypko-Clowes, M., 2017b. Neogene palaeogeography and basin evolution of the Western Carpathians, Northern Pannonian domain and adjoining areas. Global and Planetary Change,155: 133-154.

Kováčová, M., Doláková, N., Kováč, M., 2011. Miocene vegetation pattern and climate change in the Northwestern Central Paratethys domain (Czech and Slovak Republic). Geologica Carpathica, 62: 251-266.

Kovar-Eder, J., Jechorek, H., Kvaček, Z., Parashiv, V., 2008. The integrated plant record: an essential tool for reconstructing Neogene zonal vegetation in Europe. Palaios, 23: 97-111.

Krystek, I., 1974. Výsledky sedimentologického výzkumu sedimentů spodního badenu $v$ karpatské předhlubni (na Moravě) (in Czech). Folia Facultatis Scientiarum Naturalium Universitatis Purkynianae Brunensis Geologia, 15: 8.

Kvaček, Z., Kováč, M., Kovar-Eder, J., Doláková, N., Jechorek, H., Parashiv, V., Kováčová, M., Sliva, J., 2006. Miocene evolution of landscape and vegetation in the Central Paratethys. Geologica Carpathica, 57: 295-310.

Łuczkowska, E., 1998. Marine Miocene deposits of the Paratethys in Poland. Abhandlungen der Senckenbergischen Naturforschenden Gesellschaft, 549: 28-33.

Marunteanu, M., 1999. Litho- and biostratigraphy (calcareous nannoplankton) of the Miocene deposits from the Outer Moldavides. Geologica Carpathica, 50: 313-324.

Miao, Q., Thunell, R.C., 1993. Recent deep-sea benthic foraminiferal distribution in the South China Sea. Marine Micropaleontology, 22: 1-32.

Mourik, A.A., Abels, H.A., Hilgen, F.J., Di Stefano, A., Zachariasse, W.J., 2011. Improved astronomical age constraints for the middle Miocene climate transition based on high-resolution stable isotope records from the central Mediterranean Maltese Islands. Paleoceanography, 26: PA1210, doi:10.1029/2010PA001981

Murray, J.W., 2006. Ecology and Applications of Benthic Foraminifera. Cambridge University Press, Cambridge.

Nehyba, S., 2000. The cyclicity of Lower Miocene deposits of the SW part of the Carpathian Foredeep as the depositional response to sediment supply and sea-level changes. Geologica Carpathica, 51: 7-17

Nehyba, S., Šikula, J., 2007. Depositional architecture, sequence stratigraphy and geodynamic development of the Carpathian Foredeep (Czech Republic). Geologica Carpathica, 58: 53-69.

Nehyba, S., Roetzel, R., Adamová, M., 1999. Tephrostratigraphy of the Neogene volcaniclastics (Moravia, Lower Austria, Poland). Geologica Carpathica, 50: Special Issue: 126-128.

Nehyba, S., Petrová, P., Švábenická, L., 2006. Intraclasts form Lower Badenian coarse-grained deposits - evidence of lost environment (Carpathian Foredeep, Czech Republic). In: Przebieg i zmienność sedymentacji w basenach przedgórskich:
144. Instytut Geologii Podstawowej Wydział Geologii UW, Warszawa.

Nehyba, S., Petrová-Tomanová, P., Zágoršek, K., 2008 Sedimentological and palaeocological records of the evolution of the south-western part of the Carpathian Foredeep (Czech Republic) during the Early Badenian. Geological Quarterly, 52 (1): 45-60.

Nehyba, S., Holcová, K., Gedl, P., Doláková, N., 2016. The Lower Badenian transgressive-regressive cycles - a case study from Oslavany (Carpathian Foredeep, Czech Republic). Neues Jahrbuch für Geologie und Paläontologie Abhandlungen, 279: 209-238.

Ogg, J., Lugowski, A., 2017. TSCreator visualization of enhanced Geologic Time Scale 2004, database (Version 7.0; 2017), http://www.tscreator.org

Okada, H., Mclntyre, A., 1979. Seasonal distribution of modern coccolithophores in the western North Atlantic Ocean. Marine Biology, 54: 319-328.

Oszczypko, N., Oszczypko-Clowes, M., 2012. Stages of development in the Polish Carpathian Foredeep Basin. Central European Journal of Geosciences, 4: 138-162.

Oszczypko, N., Krzywiec, P., Popadyuk, I., Peryt, T., 2006 Carpathian Foredeep Basin (Polish and Ukraine): its sedimentary, structural, and geodynamic evolution. AAPG Memoir, 84: 293-350.

Papp, A., Cicha, I., Seneš, J., Steininger, F., 1978. M-4 Badenien (Moravien, Wielicien, Kosovien). Chronostratigraphie und Neostratotypen. Miozän der Zentralen Paratethys VI, VEDA, Bratislava.

Peryt, D., 2013. Foraminiferal record of the Middle Miocene climate transition prior to the Badenian salinity crisis in the Polish Carpathian Foredeep Basin (Central Paratethys). Geological Quarterly, 57 (1): 141-164.

Piller, W., Harzhauser, M., Mandic, O., 2007. Miocene Central Paratethys stratigraphy - current status and future directions. Stratigraphy, 4: 151-168.

Planderová, E., 1990. Miocene microflora of Slovak Central Paratethys and its biostratigraphical significance. Dionýz Štúr Institute of Geology, Bratislava.

Popov, S.V., Rögl, F., Rozanov, A.Y., Steininger, F.F., Shcherba, I.G., Kováč, M., 2004. Lithological-paleogeographic maps of Paratethys. 10 Maps Late Eocene to Pliocene. Courier Forschungsinstitut Senckenbergiana, 250.

Radócz, G., 2004. A Nyugat-borsodi alsó-bádeni összlet és benne a "középső riolittufa" újabb vizsgálati eredményei (in Hungarian). Földtani Közlöny, 131: 131-134

Rathburn, A.E., Corliss, B.H., 1994. The ecology of deep-sea benthic foraminifera from the Sulu Sea. Paleoceanography, 9: $87-150$

Reynolds, L., Thunell, R.C., 1985. Seasonal succession of planktonic foraminifera in the subpolar North Pacific. Journal of Foraminiferal Research, 15: 282-301.

Rögl, F., 1998. Paleogeographic considerations for Mediterranean and Paratethys seaways (Oligocene to Miocene). Annalen Naturhistorische Museum Wien, 99A: 279-310.

Rögl, F., 1999. Mediterranean and Paratethys. Facts and hypotheses of an Oligocene to Miocene paleogeography (short overview). Geologica Carpathica, 50: 339-349.

Russo, B., Curcio, E., laccarino, S., 2007. Paleoecology and paleoceanography of a Langhian succession (Tremiti Islands, southern Adriatic Sea, Italy) based on benthic foraminifera. Bollettino della Società Paleontologica Italiana, 46: 107-124.

Rybár, S., Halásová, E., Hudáčková, N., Kováč, M., Kováčová, M., Šarinová, K., Šujan, M., 2015. Biostratigraphy, sedimentology and paleoenvironments of the northern Danube Basin: Ratkovce 1 well case study. Geologica Carpathica, 66: 51-67.

Rybár, S., Kováč, M., Šarinová, K., Halásová, E., Hudáčková, N., Šujan, M., Kováčová, M., Ruman, A., Klučiar, T., 2016. Neogene changes in palaeogeography, palaeoenvironment and the provenance of sediment in the Northern Danube Basin. Bulletin of Geosciences, 91: 367-398. 
Scheiner, F., 2015. Carbon and Oxygen Stable Isotope Ratio from Foraminiferal Tests as a Key to the Paleoenvironmental Interpretations in the Middle Miocene of the Carpathian Foredeep (Central Paratethys). Msc. thesis, Charles University, Prague.

Schiebel, R., Bijma, J., Hemleben, C., 1997. Population dynamics of the planktic foraminifer Globigerina bulloides from the eastern North Atlantic. Deep Sea Research Part I: Oceanographic Research Papers, 44: 1701-1713.

Selmeczi, I., Lantos, M., Bohn-Havas, M., Nagymarosy, A., Szegö, E., 2012. Correlation of bio- and magnetostratigraphy of Badenian sequences from western and northern Hungary. Geologica Carpathica, 63: 219-232.

Sen Gupta, B.K., Machain-Castillo, M.L., 1993. Benthic foraminifera in oxygen-poor habitats. Marine Micropaleontology, 20: 183-201.

Seneš, J., 1961. Paläogeographie des Westkarpatischen Raumes in Beziehung zur übrigen Paratethys in Miozän. Geologické Práce, 60: 160-194.

Sjoerdsma, P.G., Van der Zwaan, G.J., 1992. Simulating the effect of changing organic flux and oxygen content on the distribution of benthic foraminifera. Marine Micropaleontology, 19: 163-180.

Spezzaferri, S., Ćorić, S., Stingl, K., 2009. Paleoenvironmental reconstruction of the Karpatian-Badenian (Late Burdigalian-Early Langhian) transition in the Styrian Basin (Austria): an example from the Wagna Section. Acta Geologica Polonica, 59: 523-544.

Stuchlik, L., 1994. Neogene pollen flora of Central Europe. Part 1. Acta Palaeobotanica, Supplement, 1: 1-56.

Švábenická, L., 2002. Calcareous nannofossils of the Upper Karpatian and Lower Badenian deposits in the Carpathian Foredeep, Moravia (Czech Republic). Geologica Carpathica, 53: $197-210$.

Tomanová-Petrová, P., Švábenická, L., 2007. Lower Badenian biostratigraphy and paleoecology: a case study from the Carpathian Foredeep (Czech Republic). Geologica Carpathica, 58: 333-352.

Turco, E., Cascella, A., Gennari, R., Hilgen, F., laccarino, S., Sagnotti, L., 2011. Integrated stratigraphy of the La Vedova section (Conero Riviera, Italy) and implications for the Burdigalian/Langhian boundary. Stratigraphy, 2-3: 89-110.

Vara, A., 2015. Model analysis of the role of marine gateways in the palaeoceanography of the Miocene Mediterranean and Paratethys. Utrecht Studies in Earth Sciencies, 98: 1-133.

Vass, D., 1995. The origin and disappearance of Hungarian Paleogene basins and short-term Lower Miocene basins in Northern Hungary and Southern Slovakia. Slovak Geological Magazine, 1: 81-95.
Vass, D., Elečko, M., Konečný, V., 2007. Geology of Lučenská kotlina Depression and Cerová vrchovina Upland (in Slovak). Štátny geologický ústav Dionýza Štúra, Bratislava.

Vergnaud-Grazzini, C., 1983. Reconstruction of Mediterranean Late Cenozoic hydrography by means of carbon isotope analyses. Utrecht Micropaleontological Bulletin, 30: 25-47.

Vergnaud-Grazzini, C., 1985. Mediterranean Late Cenozoic stable isotope record: stratigraphic and paleoclimatic implications. In: Geological Evolution of the Mediterranean Basin (eds. D.J. Stanley and F.-C. Wezel): 413-451. Springer, New York.

von der Heydt, A., Dijkstra, H., 2005. Ocean gateways and the thermohaline circulation through the Cenozoic. AGU Fall Meeting Abstracts, 1: 1558

Wade, B.S., Bown, P.R., 2006. Calcareous nannofossils in extreme environments: the Messinian Salinity Crisis, Polemi Basin, Cyprus. Palaeogeography, Palaeoclimatology, Palaeoecology, 233: 271-286.

Wade, B.S., Pearson, P.N., Berggren, W.A., Pälike, H., 2011. Review and revision of Cenozoic tropical planktonic foraminiferal biostratigraphy and calibration to the geomagnetic polarity and astronomical time scale. Earth-Science Reviews, 104: 111-142.

Walanus, A., Nalepka, D., 1999. POLPAL. Program for counting pollen grains, diagrams plotting and numerical analysis. Acta Palaeobotanica, 2: 659-661.

Wells, P., Okada, H., 1997. Response of nannoplankton to major changes in seasurface temperature and movements of hydrological fronts over site DSDP 594 (south Chatham Rise, southeastern New Zealand), during the last $130 \mathrm{kyr}$. Marine Micropaleontology, 32: 341-363.

Winter, A., Jordan, R.W., Roth, P.H., 1994. Biogeography of the living coccolithophores in the oceans. In: Coccolithophores (eds. A. Winter and W. Siesser): 161-178. Cambridge University Press, Cambridge.

Zachos, J.C., Pagani, M., Stone, L., Thomas, E., Billups, K., 2001. Trends, rhythms, and aberrations in global climates $65 \mathrm{Ma}$ to present. Science, 292: 686-693.

Zágoršek, K., Holcová, K., Trasoň, T., 2007. Bryozoan event from Middle Miocene (Early Badenian) lower neritic sediments from the locality Kralice nad Oslavou (Central Paratethys, Moravia part of the Carpathian Foredeep). International Journal of Earth Sciences, 97: 835-850.

Zágoršek, K., Holcová, K., Nehyba, S., Kroh, A., Hladilová, Š., 2009. The invertebrate fauna of the Middle Miocene (Lower Badenian) sediments of Kralice nad Oslavou (Central Paratethys, Moravian part of the Carpathian Foredeep). Bulletin of Geosciences, 84: 465-496. 